\title{
Repair of Fire-exposed Preloaded Rectangular Concrete Columns by Post- compressed Steel Plates
}

\author{
Lu Wang ${ }^{1}$, Ray Kai-Leung $\mathrm{Su}^{2}$
}

\section{Abstract}

This paper describes an experimental study of axially loaded, fire-exposed, rectangular reinforced concrete (RC) columns repaired with post-compressed steel plates. Seven RC columns with identical section dimensions and reinforcement details were fabricated and tested. Six of them were exposed to a four-hour fire load according to the ISO 834 Standard. After one month of cooling, five of the fireexposed columns were installed with precambered steel plates which were then post-compressed by a method newly developed by the authors. All columns were tested under axial compression to determine their ultimate load capacity, deformation and ductility. The effects of steel plate thickness, initial precamber displacements and preloading level on the ultimate load capacity of repaired RC columns were investigated. The test results show that up to $72 \%$ of the original capacity of the axial load-carrying capacity of fire-exposed columns repaired with post-compressed steel plates can be restored. Furthermore, the repaired specimens show better ductility and post-peak deformability. An analytical model was adopted to predict the ultimate axial load capacity of fire-exposed columns repaired with post-compressed steel plates. Comparison of the theoretical and experimental results reveals that the analytical model can accurately predict the ultimate axial load capacity of the repaired columns.

Keywords Reinforced concrete columns, Fire, Post-compressed, Precambered Steel Plates, Repair, Analytical model

\footnotetext{
${ }^{1}$ PhD Candidate, Dept. of Civil Engineering, The Univ. of Hong Kong, Pokfulam Rd., Hong Kong, E-mail: wanglu@hku.hk

${ }^{2}$ Associate Professor, Dept. of Civil Engineering, The Univ. of Hong Kong, Pokfulam Rd., Hong Kong, corresponding author. E-mail: klsu@hkucc.hku.hk
} 
It is well known that fires cause great loss of life and property damage in the world. In 2011, public fire departments in the United States (US) responded to 1,389,500 fires, which caused about 3005 deaths, 17,500 injuries and property damage of 12 billion US dollars. In addition, 484,500 were structural fires, accounting for 35\% of all fires, which increased by $0.5 \%$ compared to last year (Karter. 2012). Hence, to improve the safety of structures after fire exposure, there is a growing need to provide measures for post-fire repair of structural components.

When reinforced concrete (RC) columns acting as a primary load-bearing system in a building are exposed to a fire, it is more economical to repair the columns than to rebuild them to restore the original designed capacity. In the past two decades, many studies have been conducted to investigate the fire resistance of RC columns and their post-fire residual strength, stiffness and deformation (Bisby et al. 2004; Chen et al. 2009; Chowdhury et al. 2007; Han et al. 2009; Han et al. 2006; Kodur et al. 2006; 2009; Lie et al. 1996; Tao et al. 2011; Wu et al. 2007; Wu and Xu 2009; Xu and Wu 2009; Yaqub and Bailey 2011). Jau and Huang (2008) studied the fire resistance behavior of RC corner columns with 2-hour to 4-hour asymmetric fire loading under axial loading and biaxial bending. The relationship among the fire exposure time, steel ratio and thickness of cover was investigated. Kodur et al. (1998; 2003; 2004) and Raut and Kodur (2011) studied the fire resistance behavior of high strength concrete columns and high strength concrete-filled steel columns. A numerical model was proposed to evaluate the performance of high strength concrete columns exposed to fire. Many significant parameters were considered in this model, such as section dimensions, fiber reinforcement, column height, concrete strength and aggregate type. Han et al. (2001; 2002; 2003; 2004) and Han and Huo (2003) tested a large number of fire-exposed concrete-filled steel tubular columns. They developed a corresponding mathematical model for predicting the fire resistance and the fire protection thickness of the concrete-filled steel tubular columns. 
compressive strength of fire-exposed concrete-filled steel tubular columns repaired with fibrereinforced polymer (FRP) wraps was investigated (Tao and Han 2007; Tao et al. 2007). The test results demonstrated that the FRP confinement can increase the axial load-carrying capacity and stiffness of fire-exposed columns, but the strength of fire-exposed columns was not fully restored due to the long fire exposure time ( $\geq 180$ minutes). For circular columns, the axial load-carrying capacities of the FRP-strengthened short and slender columns can be restored, respectively, to $61.2 \%$ and $34.5 \%$ of the original designed capacity; for square columns, the axial load-carrying capacities of the FRPstrengthened short and slender columns can be enhanced, respectively, to $46.6 \%$ and $28.4 \%$ of the original designed capacity. Lin et al. (1995) adopted a recast concrete method to repair fire-damaged RC columns. The repair work involved removing surface layers of concrete cover, surface cleaning and patching using specially designed concrete. The test results showed that most repaired columns could recover their original capacity or develop a capacity even higher than those of unheated columns. However, no matter whether an FRP wrap or recast concrete is used to repair fire-exposed RC columns, the effects of preexisting loads on stress-lagging between the concrete core and the new jacket have yet to be determined. Ersoy et al. (1993), Takeuti et al. (2008), Giménez et al. (2009) and Su and Wang (2012) experimentally studied the effects of pre-existing loads on the strengthening efficiency. Their test results demonstrated that the stress-lagging effects can significantly reduce the ultimate axial load capacity of strengthened columns. Meanwhile, Tao and Han (2007) noted that FRP composites were more effective in enhancing the load-carrying capacity of fire-damaged circular columns than were square ones. Wang and Su (2012a; 2012b) conducted experimental and theoretical studies on the performance of preloaded RC columns strengthened with precambered steel plates under eccentric compression loads. In this approach, precambered steel plates were bolted to the RC column. Because the plates were slightly longer than the clear height of the column, progressive tightening of the anchor bolts could generate a thrust on the beam supports by means of arching action. Their results proved that precambered steel plates could actively share the existing axial loads with the original column. Stress relief in the original concrete column and post-stress developed in the steel 
plates can alleviate the stress-lagging and displacement incompatibility problems. Nonetheless, as an economical and simple strengthening method, steel jacketing that is executed by attaching steel plates or angles onto the concrete has not been thoroughly studied for repairing fire-damaged RC columns.

$$
\text { In this study, precambered steel plates together with the post-decompression method were employed }
$$
to strengthen fire-exposed preloaded RC columns. An experimental study was conducted to investigate the axial strength, post-peak deformability, ductility and internal load distributions between the concrete and the steel plates of plate-strengthened RC columns. The effectiveness of this repair method on the fire-exposed RC columns was examined. Finally, an analytical model with the consideration of the stress lagging effects was presented to predict the ultimate axial load capacity of fire-exposed RC columns repaired with post-compressed steel plates.

\section{Experimental program}

\section{Test specimens}

Seven specimens, namely FSC1 to FSC7, were fabricated and tested. The RC details of all specimens were identical. The RC cross sections were $300 \mathrm{~mm} \times 250 \mathrm{~mm}$, and the clear height of column was $850 \mathrm{~mm}$. Six high-yield deformed bars with diameter $12 \mathrm{~mm}$ (T12) were arranged as the vertical reinforcement, and the mild steel round bars with diameter $6 \mathrm{~mm}(\mathrm{R} 6)$ were adopted as the transverse reinforcement, which were applied throughout the height of the column with spacing $80 \mathrm{~mm}$. All of the specimens had the same concrete cover of $40 \mathrm{~mm}$. To prevent local failure during the load test, both ends of the specimens were slightly enlarged and properly reinforced, as shown in Fig. 1.

The design data of the specimens are summarized in Table 1. Specimen FSC1 was a control column with no repair measures and no fire load, while Specimen FSC2 was a control column exposed to fire without any repair measures. They were used to demonstrate the structural performance of an RC column and a fire-exposed RC column prior to repair. The rest of the specimens were repaired by precambered steel plates with a thickness $\left(t_{p}\right)$ of either $6 \mathrm{~mm}$ or $8 \mathrm{~mm}$. The precamber at the middle height $(\delta$ ) of columns (as shown in Figure 1) varied from $6 \mathrm{~mm}$ to $14 \mathrm{~mm}$. All of the repaired columns 
113 were subjected to a preloading level $\left(P_{p l}\right)$ before flattening the precambered steel plates, which ranged

114 from 0.21 to 0.27 of the ultimate axial load capacities of Specimen FSC1.

115

Material properties

117 The concrete has an aggregate-to-cement ratio of 4.10 and a water-to-cement ratio of 0.45 by weight. 118 The mix incorporated $10 \mathrm{~mm}$ coarse aggregates, and the slump value was approximately $65 \mathrm{~mm}$. For 119 each specimen, four $150 \mathrm{~mm} \times 150 \mathrm{~mm} \times 150 \mathrm{~mm}$ concrete cubes and four $\varnothing 150 \mathrm{~mm} \times 300 \mathrm{~mm}$ 120 cylinders were cast, and compressive tests were performed to obtain the compressive strengths on the 121 28th day and the fire test day, as shown in Table 1.

122 Two types of high-yield deformed bars and two types of mild steel round bars were used in this 123 study. Three 500-mm-long samples were taken from each type of reinforcement. Tensile tests were 124 conducted to obtain the yield strength and Young's modulus of these samples. To determine the material properties of the steel plates, six $500 \mathrm{~mm} \times 50 \mathrm{~mm}$ strips were taken from 6-mm-thick and 8mm-thick steel plates for tensile tests. The material properties of the steel reinforcements and steel plates are summarized in Table 2.

Large-scale furnace and fire exposure

130 A large-scale furnace was built for full-scale fire tests on column, wall and floor elements at the Fire 131 Laboratory of RED Fire and Facade Consultants Limited in Hong Kong, as shown in Fig. 2(a). The 132 heat was provided by eight gas burners, with four burners on each side. The temperature of the 133 concrete was monitored by K-type thermocouples that were located at various cross sections, as shown 134 in Fig. 3. The column was exposed to fire following the ISO834 standard temperature-time curve (ISO 135 1975) for four hours, as plotted in Fig. 4.

$$
T=345 \log _{10}(8 t+1)+T_{0}
$$

137 where $T$ is the fire temperature $\left({ }^{\circ} \mathrm{C}\right), t$ is the time in minutes and $T_{0}$ is the environmental temperature. 138 


\section{Setup for the axial compression test}

140 The compression test was conducted at the Structural Laboratory of South China University of 141 Technology. Loading was applied by a 15,000 kN hydraulic actuator. The upper head of the specimen 142 was connected to a hydraulic jack, and the lower end of the specimen was connected to the strong 143 floor, as shown in Fig. 2(b). All the plate-strengthened RC columns were subjected to preloading $P_{p l}=$ $144640 \mathrm{kN}$ (which is about $50 \%$ of the axial load capacity of the fire control specimen) before 145 strengthening, except Specimen FSC4 which adopted preloading $P_{p l}=830 \mathrm{kN}$. For plate-strengthened 146 specimens, the axial load was applied under force control with a loading rate at $2 \mathrm{kN}$ per second. After tightening the bolts and flattening the precambered plates, the applied load was changed to displacement control with a displacement rate of $0.008 \mathrm{~mm}$ per second. The test was terminated when the post-peak load reached $75 \%$ of the peak load.

\section{Instrumentation}

To measure the axial shortening of the columns, two linear variable displacement transducers (LVDTs) with a stroke of $30 \mathrm{~mm}$ were set symmetrically at opposite sides of the column. In each specimen, the strains in the steel plates were measured using electrical resistance linear strain gauges (TML Type FLA-5-11-3L, Tokyo Sokki Kenkyujo Co., Ltd.). Sixteen strain gauges were attached to the steel plates at four different sections along the height. The strains measured were then used to identify the failure mode and to investigate the axial load distributions in the specimens. The arrangement of LVDTs and strain gauges are depicted in Fig. 5.

\section{Test procedure}

161 The specimen was installed vertically in the furnace approximately one month after concrete casting.

162 The fire procedure was under time control. After the specimen had been forced-air cooled to room temperature, the specimen was taken out of the furnace and stored in the laboratory for one month to ensure that the residual strength of the concrete would be minimized at the time of the axial load tests. 165 Fig. 6 shows the cracks and spalls of the concrete after the fire test. To avoid local buckling of steel 
plates, the cement mortar was used to repair the spalled concrete before installing the steel plates, as shown in Fig.7(a).

To control the initial precamber of the steel plates, two stainless steel rods with a diameter equal to the initial precamber were inserted and fixed between the concrete and steel plates at the middle height of the column. The bolts at both ends of the column were then tightened to generate the designed initial precamber profile. The gaps between the steel angles and the concrete at the bottom and top of the steel plates were filled with an injection plaster, forming a layer of bedding between the steel angles and the concrete, as shown in Fig. 7(b). The injection plaster was composed of plaster, potassium sulfate and water with a proportion of $37.5: 1: 15$, by weight.

When the applied compression reached the preloading level, the post-stress procedure (Su and Wang 2012) was adopted to avoid warping or buckling of steel plates during the decompression of the RC column by flattening the precambered steel plates. Fig. 8(a) shows the post-stress procedure in detail, which can be divided into the following steps: Steps (i \& ii), bolts at the mid-height are tightened, thus, the buckling mode of the precambered plates is changed to higher modes; Step (iii), the plates are flattened by tightening the other bolts; and in Steps (iv \& v), to achieve a more evenly distributed internal stress in the plates, all the bolts are slightly loosened and re-fastened again. Fig. 8(b) and (c) show the post-stress procedure from Step (i) to Step (iii) and the strengthening details of Specimen FSC6, respectively.

\section{Test results and evaluation}

\section{Concrete temperature distribution}

Figs. 9(a) and 9(b) show the concrete temperature at various depths of the mid-height cross section (BB). As shown in Fig. 9(a), after exposure to the ISO-834 standard fire for four hours, the concrete temperature $15 \mathrm{~mm}$ from the surface reached $955{ }^{\circ} \mathrm{C}$, which was $77.5 \%$ and $143.0 \%$ greater than the concrete temperature at $70 \mathrm{~mm}\left(538{ }^{\circ} \mathrm{C}\right)$ and $125 \mathrm{~mm}\left(393^{\circ} \mathrm{C}\right)$ from surface, respectively. As shown 
in Fig. 9(b), after exposure to the fire for four hours, the concrete temperature at $50 \mathrm{~mm}$ from surface was $622^{\circ} \mathrm{C}$, which was $27.5 \%$ greater than the concrete temperature at $100 \mathrm{~mm}\left(487^{\circ} \mathrm{C}\right)$ from surface.

Figs. 9(c) and 9(d) show the concrete temperature at various heights for the same distance from the concrete surface. As shown in Fig. 9(c), after exposure to the fire for four hours, the concrete temperatures were $477{ }^{\circ} \mathrm{C}, 513^{\circ} \mathrm{C}$ and $444^{\circ} \mathrm{C}$ at Sections A-A, B-B and C-C, respectively. As shown in Fig. 9(d), after exposure to the fire for four hours, the concrete temperatures were $417{ }^{\circ} \mathrm{C}, 471^{\circ} \mathrm{C}$ and $412{ }^{\circ} \mathrm{C}$ at Sections A-A, B-B and C-C, respectively. The fire test results show that smaller distances from the concrete surface can lead to higher concrete temperatures, while the concrete temperature at the same concrete depth was evenly distributed along the column height.

\section{Strength analysis}

Compared with the post-fire control column (FSC2), the repaired specimens show various degrees of strengthening from $18.9 \%$ to $74.0 \%$, which are summarized in Table 3 . The ultimate load capacities of Specimens FSC3, FSC4, FSC5, FSC6 and FSC7 were increased by 74.0\%, 31.7\%, 18.9\%, 52.3\% and 68.2\%, respectively. Compared with the ultimate load capacity of the control column (FSC1), the ultimate load capacities of Specimens FSC3, FSC4, FSC5, FSC6 and FSC7 are restored up to 72.2\%, $54.7 \%, 49.3 \%, 63.2 \%$ and $69.8 \%$, respectively.

Fig. 10(a) shows the effects of fire on the ultimate load capacity of RC columns. Compared with the control column FSC1 $\left(P_{\text {exp }}=3085 \mathrm{kN}\right)$, the ultimate load capacity of Specimen FSC2 decreased by 58.5\%. Fig. 10 (b) shows the effects of the plate thickness $\left(t_{p}\right)$ on the ultimate load capacity $\left(P_{\text {exp }}\right)$ under the same preloading level and initial precamber. Compared with Specimen FSC2 $\left(t_{p}=0 \mathrm{~mm}\right)$, the ultimate load capacities of Specimens FSC3 $\left(t_{p}=8 \mathrm{~mm}\right)$ and FSC6 $\left(t_{p}=6 \mathrm{~mm}\right)$ increased by $74.0 \%$ and $52.3 \%$, respectively. Fig. 10 (c) shows the effects of the initial precamber $(\delta)$ on the ultimate load capacity. The ultimate load capacity of Specimen FSC7 with $\delta=14 \mathrm{~mm}$ was $2153 \mathrm{kN}$, which was $41.5 \%$ and $10.4 \%$ larger than the ultimate load capacities of Specimens FSC5 ( $\delta=6 \mathrm{~mm})$ and FSC6 $(\delta=10 \mathrm{~mm})$, respectively. Because a larger initial precamber could generate a greater post- 
compressive force in the steel plates, a greater preloading in the original RC column could therefore be 218 transferred to the steel plates. The reduction in the strain incompatibility between the steel plates and 219 concrete enhanced the ultimate load capacity of FSC7. Fig. 10(d) shows the effects of preloading level $220\left(P_{p l}\right)$ on the ultimate load capacity $\left(P_{e x p}\right)$. Compared with Specimen FSC6 $\left(P_{p l}=640 \mathrm{kN}\right)$, the ultimate 221 load capacity of Specimen FSC4 $\left(P_{p l}=830 \mathrm{kN}\right)$ decreased by $15.7 \%$. It is because the higher 222 preloading in Specimen FSC4 leading to larger locked in axial stress in the concrete. Hence, the steel 223 plate strength utilisation coefficient $(\gamma)$ defined in Equation (11) is lower than that of Specimen FSC6. 224 The results clearly demonstrate that the use of thicker plates or increasing the initial precamber of plates can achieve a significantly higher ultimate load capacity.

\section{Crack patterns and failure modes}

228 The concrete crack patterns of all of the specimens were quite similar after load tests. The initial concrete cracks usually occurred at the mid-height of the columns and then propagated in the vertical direction. With an increasing applied load, the major cracks were extended, and the concrete was spalled, as shown in Fig. 11. Judging from the readings of the strain gauges attached to the steel plates, the failure modes of specimens were identified. To avoid plate local buckling, the bolt spacing of 180 mm was adopted so that the critical buckling stress was larger than the yield stress of steel plates. According to the strain readings, once the concrete crushing occurred, the steel plates reached their yield strength rapidly because the resistance force originally provided by the concrete was changed to that provided by the steel plates.

\section{Deformation and Ductility}

239 The deformability factor $(\lambda)$, which is defined in Equation (2) by De Luca et al. (2011), was adopted to 240 evaluate the deformation performance of the repaired columns.

$$
\lambda=\Delta_{f} / \Delta_{u}
$$


in which $\Delta_{u}$ is the axial shortening at the ultimate load and $\Delta_{f}$ is the axial shortening at the failure load, 243 which is equal to $75 \%$ of the ultimate load. The deformability factors of specimens were calculated, 244 and the results, ranging from 1.12 (Specimen FSC1) to 1.73 (Specimen FSC3), are summarized in 245 Table 3. Compared with the control column, the deformability factor of the post-fire control column (FSC2) was 1.19, an increase of only 6.3\%. However, the deformability factors of Specimens FSC3, FSC4, FSC5, FSC6 and FSC7 were increased by 54.5\%, 39.3\%, 19.6\%, 38.4\% and 34.8\%, respectively. Thus, the plate thickness plays an important role in increasing the deformability of the repaired columns.

The displacement ductility factor $(\eta)$ is introduced to evaluate the ductility performance of the repaired columns, which is defined as the ratio of the axial shortening at the ultimate load $\left(\Delta_{u}\right)$ to the notional yield displacement $\left(\Delta_{y}\right)$ (Su et al. 2010), thus

$$
\eta=\Delta_{u} / \Delta_{y}
$$

As shown in Table 3, the displacement ductility factors range from 1.09 (for Specimen FSC1) to 2.21 (for Specimen FSC3). Compared with the control column, the displacement ductility factor of the post-fire control column (FSC2) was 1.42, increased by 30.3\%. Compared with Specimen FSC5 ( $\delta=6$ $\mathrm{mm})$, the displacement ductility factors of Specimens FSC6 $(\delta=10 \mathrm{~mm})$ and FSC7 $(\delta=14 \mathrm{~mm})$ were increased by $20.8 \%$ and $21.4 \%$, respectively. The difference of the displacement ductility factors between Specimens FSC6 and FSC7 was only 0.6\%. It is because the plate strength utilization coefficients $(\gamma)$ of Specimens FSC6 $(\gamma=0.90)$ and FSC7 $(\gamma=0.99)$ were quite similar, while their coefficients were much higher than that of Specimen FSC5 $(\gamma=0.68)$. Using thicker plates $\left(t_{p}=8 \mathrm{~mm}\right)$ for Specimen FSC3 instead of thinner plates $\left(t_{p}=6 \mathrm{~mm}\right)$ for Specimen FSC6, the displacement ductility factor of FSC3 was increased by $5.7 \%$. Compared with Specimen FSC6 $\left(P_{p l}=640 \mathrm{kN}\right)$, the displacement ductility factor of Specimen FSC4 $\left(P_{p l}=830 \mathrm{kN}\right)$ was slightly increased by $1.0 \%$. Hence, using a larger initial precamber (which led to higher plate strength utilization) and thicker steel plates could effectively improve the displacement ductility, while the effect of the preloading level on the displacement ductility was relatively small. 


\section{Distribution of axial forces between steel plates and concrete}

270 The distribution of loads between the original RC column and the steel plates is a key issue in this 271 study. Sixteen strain gauges were pasted at four different sections on the steel plates to evaluate this 272 distribution, as shown in Fig. 5. The load distributions of strengthened columns FSC3, FSC4, FSC5, 273 FSC6 and FSC7 at three different loading stages including (i) the preloading (after tightening the 274 bolts), (ii) 75\% of the peak load and (iii) the peak load are summarized in Table 4 . These figures show 275 that the axial load was almost uniformly distributed across the height of the plates. For Specimen 276 FSC3, the largest variation in the axial load distribution was only $55 \mathrm{kN}$ when the load reached $75 \%$ of 277 the peak load. For Specimen FSC4, the largest axial load variation was $84 \mathrm{kN}$, which occurred 278 between Section 1 and Section 3 at the peak loading stage. For Specimens FSC5 and FSC6, the largest 279 axial load variations were $77 \mathrm{kN}$ and $67 \mathrm{kN}$, respectively. For Specimen FSC7, the largest variation 280 was $89 \mathrm{kN}$, which occurred between Section 1 and Section 2 at $75 \%$ of the ultimate load. These results 281 suggest that the proposed post-stress procedure is an effective means to achieve axial load sharing 282 between the original column and the additional steel plates.

\section{Analytical model}

\section{Residual strength of concrete and steel bars}

286 It is well known that compressive strength of concrete would vary according to the fire exposure time. 287 The residual strength of concrete $\left(f_{c r}{ }^{\prime}\right)$ may be estimated by Equation (4) (Tan and Yao, 2003).

$$
f_{c r}^{\prime}=\beta_{c} \times f_{c}^{\prime}
$$

289 where $f_{c}$ ' is the cylinder compressive strength of concrete, and $\beta_{c}$ is the strength reduction factor for 290 concrete, which can be determined by Equation (5) (Dotreppe et al., 1997).

$$
\beta_{c}=\frac{\mu}{\sqrt{1+\left(0.3 A_{c}^{-0.5} t_{I S O}\right)^{A_{c}^{-0.25}}}}
$$


292

293

in which $A_{c}$ is the cross sectional area of RC column in $\mathrm{m}^{2}, t_{\mathrm{ISO}}$ is the ISO 834 fire exposure time in hours, and $\mu$ is the factor to account for spalling of concrete, which can be obtained by Equation (6).

$$
\mu=\left\{\begin{array}{cc}
1-0.3 t_{\text {ISO }} & \left(t_{\text {ISO }} \leq 0.5 \text { hour }\right) \\
0.85 & \left(t_{\text {ISO }}>0.5 \text { hour }\right)
\end{array}\right.
$$

The residual strength of steel bars $\left(f_{s y}{ }^{\prime}\right)$ can be determined by Equation (7) (Lie, 1992).

$$
f_{s y}^{\prime}=\left\{\begin{array}{cl}
f_{s y}\left[1.0+\frac{T}{900 \ln \left(\frac{T}{1750}\right)}\right] & \left(0<T \leq 600^{\circ} \mathrm{C}\right) \\
f_{s y}\left(\frac{340-0.34 T}{T-240}\right) & \left(600^{\circ} \mathrm{C}<T<1000^{\circ} \mathrm{C}\right)
\end{array}\right.
$$

297 where $f_{s y}$ is the yield strength of steel reinforcement, and $T$ is the temperature of steel bar.

298

299

\section{Ultimate load capacity of repaired columns}

300 Su and Wang (2012) proposed a theoretical model to predict the ultimate axial load capacity of RC 301 column strengthened with post-compressed steel plates. The theory of this method is similar to the principle of pre-stressed concrete. The amount of post-compressed plate forces induced is controlled by the initial precamber of the precambered plates. The ultimate axial load capacity $\left(P_{\text {pre }}\right)$ of the platerepaired column is expressed as

$$
P_{p r e}=0.85 A_{c} f_{c r}^{\prime}+A_{s} f_{s y}^{\prime}+2 \gamma A_{p} f_{p y}
$$

where $A_{s}$ and $A_{p}$ are the cross-sectional area of longitudinal reinforcement and steel plates respectively,

$f_{p y}$ is the yield strength of steel plates, and $\gamma$ is the plate strength utilisation coefficient, which can be 308 estimated as

$$
\gamma=\left\{\begin{array}{cc}
\frac{E_{p}\left(\varepsilon_{c o}-\varepsilon_{c, p s}\right)}{f_{p y}} & \left(\varepsilon_{c o}-\varepsilon_{c, p s}<\varepsilon_{p y}\right) \\
1 & \left(\varepsilon_{c o}-\varepsilon_{c, p s} \geq \varepsilon_{p y}\right)
\end{array}\right.
$$

where $E_{p}$ is Young's moduli of steel plates, $\varepsilon_{c o}$ is the concrete compressive strain corresponding to $f_{c}$, $311 \varepsilon_{p y}$ is the yield strain of the steel plates, and $\varepsilon_{c, p s}$ is the concrete strain at the post-stressing stage, which can be determined from Equation (10), 


$$
\varepsilon_{c, p s}=\frac{\varepsilon_{c 0}\left(2 A_{c} f_{c}^{\prime}+E_{s} A_{s} \varepsilon_{c 0}-\sqrt{4 A_{c} f_{c}^{\prime}\left(A_{c} f_{c}^{\prime}+E_{s} A_{s} \varepsilon_{c 0}+2 E_{p} A_{p} \varepsilon_{p, p s}-P_{p l}\right)+E_{s}^{2} A_{s}^{2} \varepsilon_{c 0}^{2}}\right)}{2 A_{c} f_{c}^{\prime}}
$$

314 where $E_{s}$ is Young's moduli of longitudinal reinforcement, $P_{p l}$ is the preloading, and $\varepsilon_{p, p s}$ is the strain 315 of steel plate when the precambered plate was flattened, which can be determined by Equation (11),

$$
\varepsilon_{p, p s}=\left[\left(\frac{(\pi \delta)^{2}}{4 L_{r c, p l}}\right)\left(\frac{2 K_{p} K_{r c, p l}}{2 K_{p}+K_{r c, p l}}\right)\right] /\left(E_{p} A_{p}\right)
$$

where $L_{r c, p l}$ is the clear height of the RC column under preloading $\left(P_{p l}\right), \delta$ is the initial precamber at the mid-height of the plate, and $K_{p}$ and $K_{r c, p l}$ are the axial stiffnesses of a steel plate and RC column respectively, which can be determined from Equation (12) and Equation (13), respectively.

$$
K_{r c, p l}=\frac{E_{c} A_{c}}{L_{r c, p l}}
$$

$$
K_{p}=\frac{E_{p} A_{p}}{L_{p}}
$$

322 where $L_{p}$ is the length of the steel plate.

\section{Fire resistance requirements for repaired columns}

Due to the use of steel plates, fire protection of the structural steel should be a concern. A common fire protection for repaired columns is to box in using gypsum wallboard, as shown in Fig.12. The fire resistance of the repaired columns protected by gypsum wallboard can be determined by Equation (14) (ASCE/SEI/SFPE 2007).

$$
R=1.6\left(\frac{h \frac{W^{\prime}}{D}}{2}\right)^{0.75}
$$

where $R$ is the fire resistance in minutes, $h$ is the thickness of gypsum wallboard in mm, $D$ is the heated perimeter in mm, and $W^{\prime}$ is the weight of steel and gypsum wallboard protection per foot length in $\mathrm{kg} / \mathrm{m}$, which can be determined by Equation (15) (ASCE/SEI/SFPE 2007).

$$
W^{\prime}=W+0.0008 h D
$$


where $W$ is the average weight of the steel in $\mathrm{kg} / \mathrm{m}$.

\section{Comparison between the predicted and experimental results}

Using Equations (8) to (13), the ultimate axial load capacity of repaired columns was evaluated. The predicted axial load capacity $\left(P_{\text {pre }}\right)$ of the specimens is listed in Table 3 . It is noted that the strain of concrete corresponding to the peak load $\left(\varepsilon_{c o}\right)$ was taken as 0.002 in the calculation. Comparing the theoretical and experimental axial load capacities reveals that the analytical model is generally able to conservatively estimate the axial load capacity of fire-exposed RC columns repaired with postcompressed steel plates with an average underestimation of $12 \%$.

\section{Conclusions}

345 This paper presents a study on the axial strengthening of fire-exposed RC columns using postcompressed steel plates under axial compression loading. The main findings of this study can be summarized as follows:

(1) The axial load-carry capacity of RC columns with a cross section of $300 \mathrm{~mm} \times 250 \mathrm{~mm}$ can decrease drastically when the columns are subjected to a four-hour fire load. The concrete temperature increases sharply in the concrete cover near the concrete surface.

(2) Compared with the test results of Tao and Han (2007), the proposed repairing method by postcompressed steel plates is more effective in restoring the axial load-carrying capacity of fireexposed concrete rectangular columns than FRP wraps.

(4) The experimental results show that post-compressed precambered steel plates can share the

(3) Test results show that the axial load-carrying capacity of four-hour fire-exposed columns repaired existing axial load in the original column. Stress-lagging effects can be alleviated by controlling the initial precambered profile of the steel plates. 
360 (5) External steel plates can considerably enhance the axial strength and the deformation capacity of 361 plate-strengthened columns under axial compression loading.

362 (6) Thicker steel plates and a larger initial precamber can enhance the ultimate load capacity of 363 columns. The use of a larger plate thickness can also improve the axial deformation capacity of 364 columns significantly.

365 (7) An analytical model to predict the ultimate axial load capacity of fire-exposed columns repaired 366 with post-compressed steel plates was described. The comparison between the theoretical and experimental results indicates that the model adopted can accurately predict the ultimate axial load capacity of plate-repaired columns.

\section{ACKNOWLEDGMENTS}

371 The research described here was supported by the Research Grants Council of the Hong Kong SAR 372 (Project No. HKU7166/08E) and The University of Hong Kong through Small Project Funding 20103732011. 
REFERENCES

376 ASCE/SEI/SFPE 29-05 (2007) Standard calculation method for structural fire protection, American Society of Civil Engineers, Reston, VA.

378

379

380

381

382

383

384

Bisby, L. A., Kodur, V. K. R., and Green, M. F. (2004). “Numerical parametric studies on the fire endurance of fibre-reinforced-polymer-confined concrete columns.' Canadian Journal of Civil Engineering, 31(6), 1090-1100.

Chen, Y. H., Chang, Y. F., Yao, G. C., and Sheu, M. S. (2009). "Experimental research on post-fire behaviour of reinforced concrete columns.” Fire Safety Journal, 44(5), 741-748.

Chowdhury, E. U., Bisby, L. A., Green, M. F., and Kodur, V. K. R. (2007). "Investigation of insulated FRP-wrapped reinforced concrete columns in fire.” Fire Safety Journal, 42(6), 452-460.

De Luca, A., Nardone, F., Matta, F., Nanni, A., Liqnola, G., and Prota, A. (2011). “Structural evaluation of full-scale FRP-confined reinforced concrete columns.” Journal of Composites for Construction, 15(1), 112-123.

Dotreppe, J. C., Franssen, J. M., Bruls, A., Vandevelde, P., Minne, R., Van Nieuwenburg, D., and Lambotte, H. (1997). "Experimental research on the determination of the main parameters affecting the behavior of reinforced concrete columns under fire conditions.” Magazine of Concrete Research, 49(179), 117-127.

Ersoy, U., Suleiman, R. and Tankut, T. (1993). "Behavior of jacketed columns.” ACI Structural Journal, 90(3), 288-293.

Giménez, E., Adam, J.M., Ivorra, S., Moragues, J.J., and Calderón, P.A. (2009). “Full-scale testing of axially loaded RC columns strengthened by steel angles and strips.” Advances in Structural Engineering, 12(2), 169-181.

Han, C. G., Han, M. C., and Heo, Y. S. (2009) “Improvement of residual compressive strength and spalling resistance of high-strength RC columns subjected to fire.” Construction and Building Materials, 23(1), 107-116. 
Han, L. H. (2001). "Fire performance of concrete filled steel tubular beam-columns.” Journal of $401 \quad$ Constructional Steel Research, 57(6), 697-711.

402 Han, L. H., Zheng, Y. Q., and Teng, J. G. (2006). "Fire resistance of RC and FRP-confined RC 403 columns.” Magazine of Concrete Research, 58(8), 533-546.

404 Han, L. H., Yang, Y. F., Yang, H., and Huo, J. S. (2002). "Residual strength of concrete-filled RHS 405 columns after exposure to the ISO-834 standard fire.” Thin-Walled Structures, 40(12), 991-1012.

406 Han, L. H., Zhao, X. Y., Yang, Y. F., and Feng, J. B. (2003). “Experimental study and calculation of 407 fire resistance of concrete-filled hollow steel columns.” Journal of Structural Engineering, 129(3), $408 \quad 346-356$.

409 Han, L. H., and Huo, J. S. (2003). “Concrete-filled hollow structural steel columns after exposure to $410 \quad$ ISO-834 fire standard.” Journal of Structural Engineering, 129(1), 68-78.

411 Han, L. H., Yang, Y. F., and Xu, L. (2003). “An experimental study and calculation on the fire 412 resistance of concrete-filled SHS and RHS columns.” Journal of Constructional Steel Research, $413 \quad 59(4), 427-452$.

414 Han, L. H., and Lin, X. K. (2004). “Tests on cyclic behavior of concrete-filled hollow structural steel 415 columns after exposure to the ISO-834 standard fire.” Journal of Structural Engineering, 130(11), $416 \quad 1807-1809$.

417 ISO. (1975). “Fire resistance test—elements of building construction.” ISO 834, Geneva.

418 Jau, W. C., and Huang, K. L. (2008). “A study of reinforced concrete corner columns after fire.” 419 Cement and Concrete Composites, 30(7), 622-638.

420 Karter, M. J. (2012). “Fire loss in the united states during 2011.” Fire Analysis and Research Division, $421 \quad$ National Fire Protection Association, MA, USA.

422 Kodur, V. K. R., and Raut, N. K. (2009). “Design equation for predicting fire resistance of reinforced 423 concrete columns.” Structural Concrete, 10(2), 73-86. 
Kodur, V. K. R., Bisby, L. A., and Green, M. F. (2006). "Experimental evaluation of the fire behaviour of insulated fibre-reinforced-polymer-strengthened reinforced concrete columns.” Fire Safety Journal, 41(7), 547-557.

Kodur, V. K. R. (1999). “Performance-based fire resistance design of concrete-filled steel columns.” Journal of Constructional Steel Research, 51(1), 21-26.

Kodur, V. K. R. (1998). “Performance of high strength concrete-filled steel columns exposed to fire.’” Canadian Journal of Civil Engineering, 25(6), 975-981.

Kodur, V. K. R., Cheng, F. P., Wang, T. C., and Sultan, M. A. (2003). “Effect of strength and fiber reinforcement on fire resistance of high-strength concrete columns.” Journal of Structural Engineering, 129(2), 253-259.

Kodur, V. K. R., Wang, T. C., and Cheng, F. P. (2004). "Predicting the fire resistance behaviour of high strength concrete columns.” Cement and Concrete Composites, 26(2), 141-153.

Lie, T. T. (1992). “ASCE Manuals and Reports on Engineering Practice No. 78-Structural Fire Protection.” American Society of Civil Engineers, New York.

Lie, T. T., and Kodur, V. K. R. (1996). “Fire resistance of steel columns filled with bar-reinforced concrete.” Journal of structural engineering New York, 122(1), 30-36.

Lin, C. H., Chen, S. T., and Yang, C. A. (1995). "Repair of fire-damaged reinforced concrete columns.” ACI Materials Journal, 92(4), 406-411.

Raut, N. K., and Kodur, V. K. R. (2011). “Response of high-strength concrete columns under design fire exposure.” Journal of Structural Engineering, 137(1), 69-79.

Su, R.K.L., Cheng, B., Wang, L., Siu, W.H. and Zhu, Y. (2011). "Use of bolted steel plates for strengthening of reinforced concrete beams and columns”, The IES Journal Part A: Civil \& Structural Engineering, 4(2), 55-68.

Su, R.K.L., Siu, W.H. and Smith, S.T. (2010). "Effects of bolt-plate arrangements on steel plate strengthened reinforced concrete beams.” Engineering Structures, 32(6), 1769-1778. 
Su, R.K.L., and Wang, L. (2012). “Axial strengthening of preloaded rectangular concrete columns by precambered steel plates.” Engineering Structures, 38(5), 42-52.

Takeuti, R.A., de Hanai, J.B. and Mirmiran, A. (2008). "Preloaded RC columns strengthened with high-strength concrete jackets under uniaxial compression.” Materials and Structures, 41(7), 1251-1262.

Tan, K. H., and Yao, Y. (2003). “Fire Resistance of Four-Face Heated Reinforced Concrete Columns.” Journal of Structural Engineering, 129(9), 1220-1229.

Tao, Z., Wang, Z. B., Han, L. H., and Brian, B. (2011) "Fire performance of concrete-filled steel tubular columns strengthened by CFRP.” Steel and Composite Structures, 11(4), 307-324.

Tao, Z., and Han, L. H. (2007) "Behaviour of fire-exposed concrete-filled steel tubular beam columns repaired with CFRP wraps.” Thin-Walled Structures, 45(1), 63-76.

Tao, Z., Han, L. H., and Wang, L. L. (2007) “Compressive and flexural behaviour of CFRP-repaired concrete-filled steel tubes after exposure to fire.” Journal of Constructional Steel Research, 63(8), 1116-1126.

Wang, L. and Su, R.K.L. (2012a). “Experimental investigation of preloaded RC columns strengthened with precambered steel plates under eccentric compression loading.” Advances in Structural Engineering, (Article in press).

Wang, L. and Su, R.K.L. (2012b). “Theoretical and experimental study of plate-strengthened concrete columns under eccentric compression loading.” Journal of Structural Engineering, (Article in press).

Wu, B., Hong, Z., Tang, G. H., and Wang, C. (2007). “Fire resistance of reinforced concrete columns with square cross section.” Advances in Structural Engineering, 10(4), 353-369.

Wu, B., and Xu, Y. Y. (2009). "Behavior of axially-and-rotationally restrained concrete columns with '+'-shaped cross section and subjected to fire.” Fire Safety Journal, 44(2), 212-218.

Xu, Y. Y., and Wu, B. (2009). "Fire resistance of reinforced concrete columns with L-, T-, and +shaped cross-sections.” Fire Safety Journal, 44(6), 869-880. 
Table 1. Summary of the material and geometry properties for repair works

\begin{tabular}{c|c|c|c|c|c|c|c|c|c}
\hline Specimen & $\begin{array}{c}f_{c u, s} \\
(\mathrm{MPa})\end{array}$ & $\begin{array}{c}f_{c, s} \\
(\mathrm{MPa})\end{array}$ & $\begin{array}{c}f_{c u, t} \\
(\mathrm{MPa})\end{array}$ & $\begin{array}{c}f_{c, t} \\
(\mathrm{MPa})\end{array}$ & $\begin{array}{c}L_{r c} \\
(\mathrm{~mm})\end{array}$ & $\begin{array}{c}t \\
(\mathrm{~min})\end{array}$ & $\begin{array}{c}t_{p} \\
(\mathrm{~mm})\end{array}$ & $\begin{array}{c}\delta \\
(\mathrm{mm})\end{array}$ & $\begin{array}{c}P_{p l} \\
(\mathrm{kN})\end{array}$ \\
\hline FSC1 & 53.2 & 48.3 & 54.1 & 48.8 & 850 & - & - & - & - \\
FSC2 & 53.2 & 48.3 & 54.1 & 48.8 & 850 & 240 & - & - & - \\
FSC3 & 52.4 & 46.5 & 52.8 & 46.7 & 850 & 240 & 8 & 10 & 640 \\
FSC4 & 52.4 & 46.5 & 52.8 & 46.7 & 850 & 240 & 6 & 10 & 830 \\
FSC5 & 54.2 & 47.8 & 54.7 & 47.8 & 850 & 240 & 6 & 6 & 640 \\
FSC6 & 54.2 & 47.8 & 54.7 & 47.8 & 850 & 240 & 6 & 10 & 640 \\
FSC7 & 54.9 & 46.3 & 54.9 & 46.3 & 850 & 240 & 6 & 14 & 640 \\
\hline
\end{tabular}

Note: $f_{c u, s}$ is the concrete cube compression strength on the 28th day;

$f_{c, s}$ is the concrete cylinder compression strength on the 28th day;

$f_{c u, t}$ is the concrete cube compression strength on the fire test day;

$f_{c, t}$ is the concrete cylinder compression strength on the fire test day.

Table 2. Material properties of reinforcements and steel plates

\begin{tabular}{c|c|c}
\hline \multicolumn{3}{|c}{ Steel Plate } \\
\hline Thickness & $f_{y p}(\mathrm{MPa})$ & $E_{p}(\mathrm{GPa})$ \\
\hline $6 \mathrm{~mm}$ & 329 & 209 \\
$8 \mathrm{~mm}$ & 322 & 195 \\
\hline
\end{tabular}

\begin{tabular}{c|c|c}
\hline \multicolumn{3}{|c}{ Reinforcement bars } \\
\hline Specimen & $f_{y}(\mathrm{MPa})$ & $E_{\mathrm{s}}(\mathrm{GPa})$ \\
\hline T12 & 516 & 198 \\
T16 & 507 & 196 \\
R6 & 464 & 186 \\
R8 & 437 & 187 \\
\hline
\end{tabular}

Table 3. Summary of deformability and ductility factors, axial load capacities and predicted values

\begin{tabular}{c|c|c|c|c|c|c|c|c}
\hline Specimen & $\begin{array}{c}\Delta_{y} \\
(\mathrm{~mm})\end{array}$ & $\begin{array}{c}\Delta_{u} \\
(\mathrm{~mm})\end{array}$ & $\begin{array}{c}\Delta_{f} \\
(\mathrm{~mm})\end{array}$ & $\lambda$ & $\eta$ & $\begin{array}{c}P_{\text {exp }} \\
(\mathrm{kN})\end{array}$ & $\begin{array}{c}P_{\text {pre }} \\
(\mathrm{kN})\end{array}$ & $P_{\text {exp }} / P_{\text {pre }}$ \\
\hline FSC1 & 2.55 & 2.77 & 3.11 & 1.12 & 1.09 & 3085 & 3020 & 1.02 \\
FSC2 & 4.77 & 6.75 & 8.03 & 1.19 & 1.42 & 1280 & 1012 & 1.26 \\
FSC3 & 3.53 & 7.79 & 13.41 & 1.73 & 2.21 & 2227 & 1911 & 1.17 \\
FSC4 & 2.77 & 5.85 & 9.13 & 1.56 & 2.11 & 1686 & 1479 & 1.14 \\
FSC5 & 5.22 & 6.99 & 9.36 & 1.34 & 1.73 & 1522 & 1490 & 1.02 \\
FSC6 & 3.48 & 7.27 & 11.28 & 1.55 & 2.09 & 1950 & 1738 & 1.12 \\
FSC7 & 3.39 & 7.13 & 10.78 & 1.51 & 2.10 & 2153 & 1913 & 1.13 \\
\hline Mean & - & - & - & - & - & - & - & 1.12 \\
\hline
\end{tabular}


Table 4. Internal load distributions of strengthened columns

\begin{tabular}{|c|c|c|c|c|c|c|c|c|c|c|c|c|}
\hline \multirow{3}{*}{ Section } & \multicolumn{6}{|c|}{ FSC3 } & \multicolumn{6}{|c|}{ FSC4 } \\
\hline & \multicolumn{2}{|c|}{ Post-stress } & \multicolumn{2}{|c|}{$75 \% P_{\text {exp }}$} & \multicolumn{2}{|c|}{$P_{\text {exp }}$} & \multicolumn{2}{|c|}{ Post-stress } & \multicolumn{2}{|c|}{$75 \% P_{\exp }$} & \multicolumn{2}{|c|}{$P_{\text {exp }}$} \\
\hline & $P_{p c}$ & $P_{r c}$ & $P_{p c}$ & $P_{r c}$ & $P_{p c}$ & $P_{r c}$ & $P_{p c}$ & $P_{r c}$ & $P_{p c}$ & $P_{r c}$ & $P_{p c}$ & $P_{r c}$ \\
\hline 1 & 388 & 252 & 977 & 693 & 1305 & 922 & 363 & 467 & 593 & 672 & 743 & 943 \\
\hline 2 & 379 & 261 & 966 & 704 & 1313 & 914 & 361 & 469 & 608 & 657 & 720 & 966 \\
\hline 3 & 411 & 229 & 1021 & 649 & 1332 & 895 & 344 & 486 & 577 & 688 & 659 & 1027 \\
\hline \multirow[t]{2}{*}{4} & 404 & 236 & 973 & 697 & 1321 & 906 & 381 & 449 & 584 & 681 & 707 & 979 \\
\hline & \multicolumn{6}{|c|}{ FSC5 } & \multicolumn{6}{|c|}{ FSC6 } \\
\hline 1 & 296 & 344 & 616 & 524 & 845 & 675 & 336 & 274 & 766 & 697 & 955 & 995 \\
\hline 2 & 271 & 369 & 617 & 523 & 864 & 656 & 361 & 279 & 779 & 684 & 964 & 986 \\
\hline 3 & 324 & 316 & 637 & 503 & 922 & 598 & 344 & 296 & 797 & 666 & 1015 & 935 \\
\hline \multirow[t]{2}{*}{4} & 311 & 329 & 661 & 479 & 915 & 605 & 342 & 298 & 811 & 652 & 1022 & 928 \\
\hline & \multicolumn{6}{|c|}{ FSC7 } & & & & & & \\
\hline 1 & 380 & 260 & 867 & 747 & 1185 & 968 & \multirow{4}{*}{\multicolumn{6}{|c|}{$\begin{aligned} \text { Note: } & P_{p c} \text { is the axial compressive load } \\
& \text { of steel plates in } \mathrm{kN} \text {; } \\
& P_{r c} \text { is the axial compressive load } \\
& \text { of } \mathrm{RC} \text { column in } \mathrm{kN} \text {. }\end{aligned}$}} \\
\hline 2 & 389 & 251 & 956 & 658 & 1233 & 920 & & & & & & \\
\hline 3 & 412 & 228 & 871 & 743 & 1262 & 891 & & & & & & \\
\hline 4 & 344 & 296 & 913 & 701 & 1201 & 952 & & & & & & \\
\hline
\end{tabular}

496

$497 \quad$ A List of Figure Captions

498 Figure 1. The specimen configuration: (a) Elevation; (b) Cross section

499 Figure 2. Test setup: (a) Photograph of the furnace; (b) Photograph of the compression machine

500 Figure 3. Positions of the thermocouples in the concrete

501 Figure 4. Measured furnace temperature $(T)$ versus time $(t)$

502 Figure 5. Instrumentation of Specimen FSC6

503 Figure 6. Crack and spalls of specimens after the fire test

504 Figure 7. Post-stressed procedure (a) Cement mortar repairing of FSC5 and (b) Injection plaster filled 505 in the gaps

506 Figure 8. Post-stressed procedure (a) Schematic diagram, (b) The Steps (i) to (iii) of FSC6 and (c) 507 Strengthening details of FSC6

508 Figure 9. Concrete temperature versus time: (a) Section B-B of FSC4; (b) Section B-B of FSC7; (c) 70 509 $\mathrm{mm}$ from the surface of FSC2; (d) $125 \mathrm{~mm}$ from the surface of FSC5 
510 Figure 10. Axial compression-shortening curves of the specimens: (a) Effects of fire exposure; (b) Effects of plate thickness; (c) Effects of initial precamber; (d) Effects of preloading level

512 Figure 11. Crack patterns and failure mode

513 Figure 12. Repaired columns fire protected by gypsum wallboard 514 


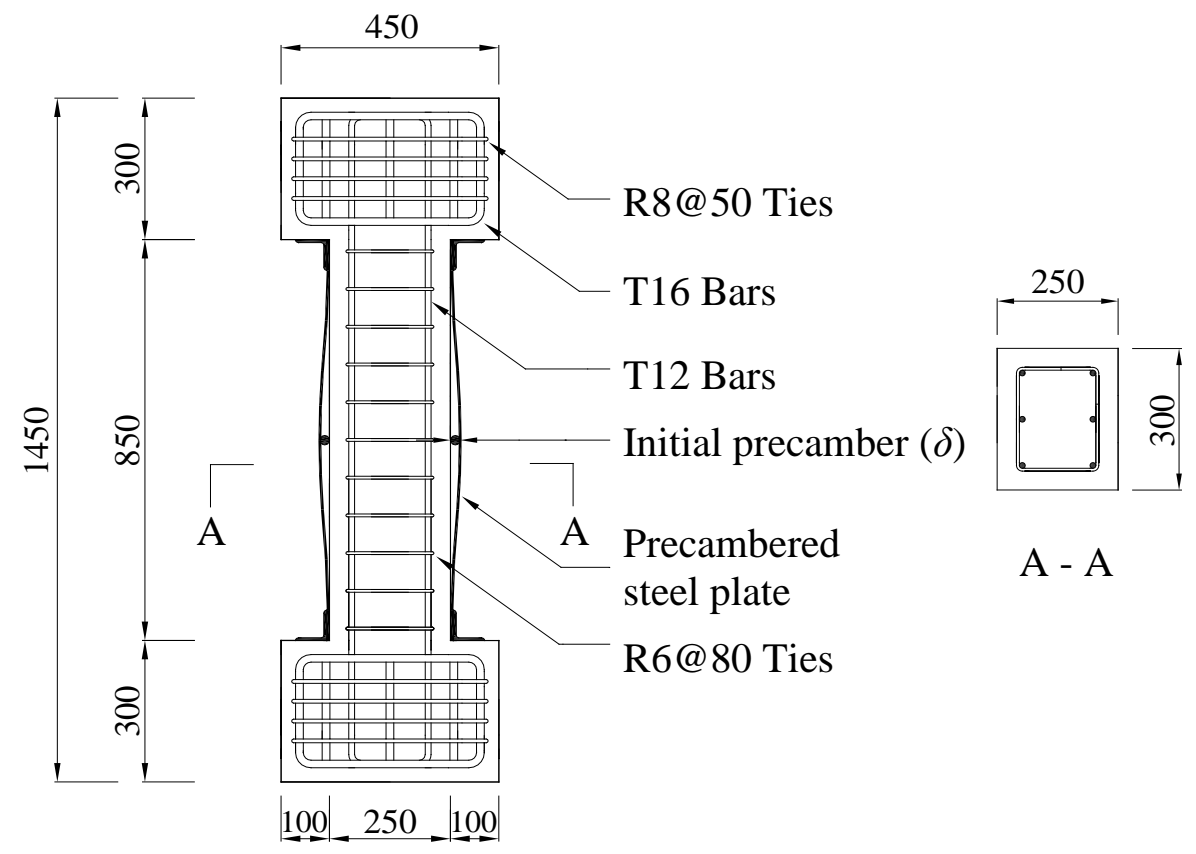

(a)

(b)

Fig. 1. The specimen configuration: (a) Elevation; (b) Cross section

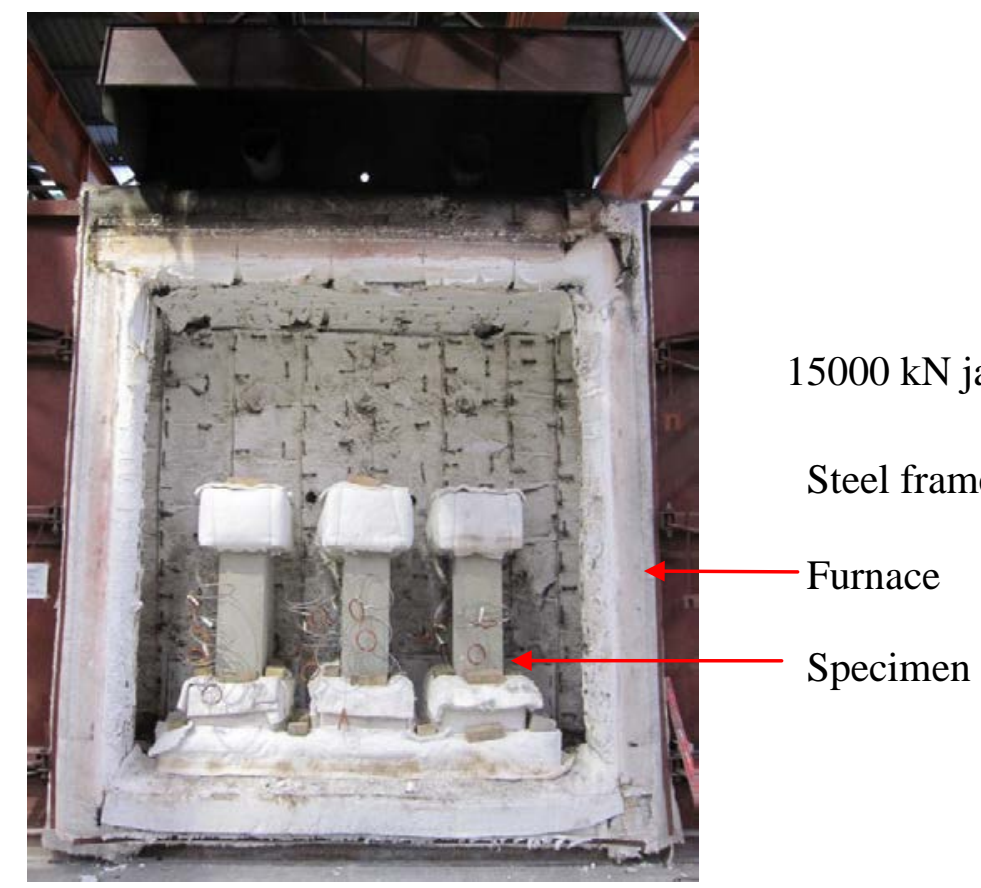

(a)

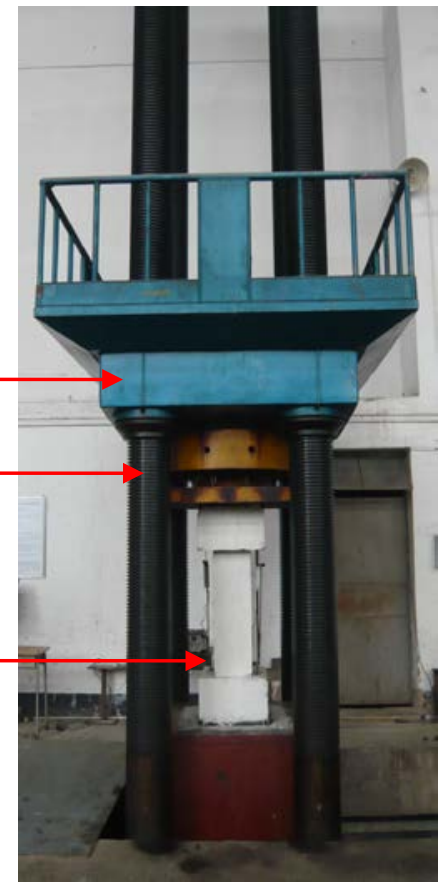

(b)

Fig. 2. Test setup: (a) Photograph of the furnace; (b) Photograph of the compression machine 


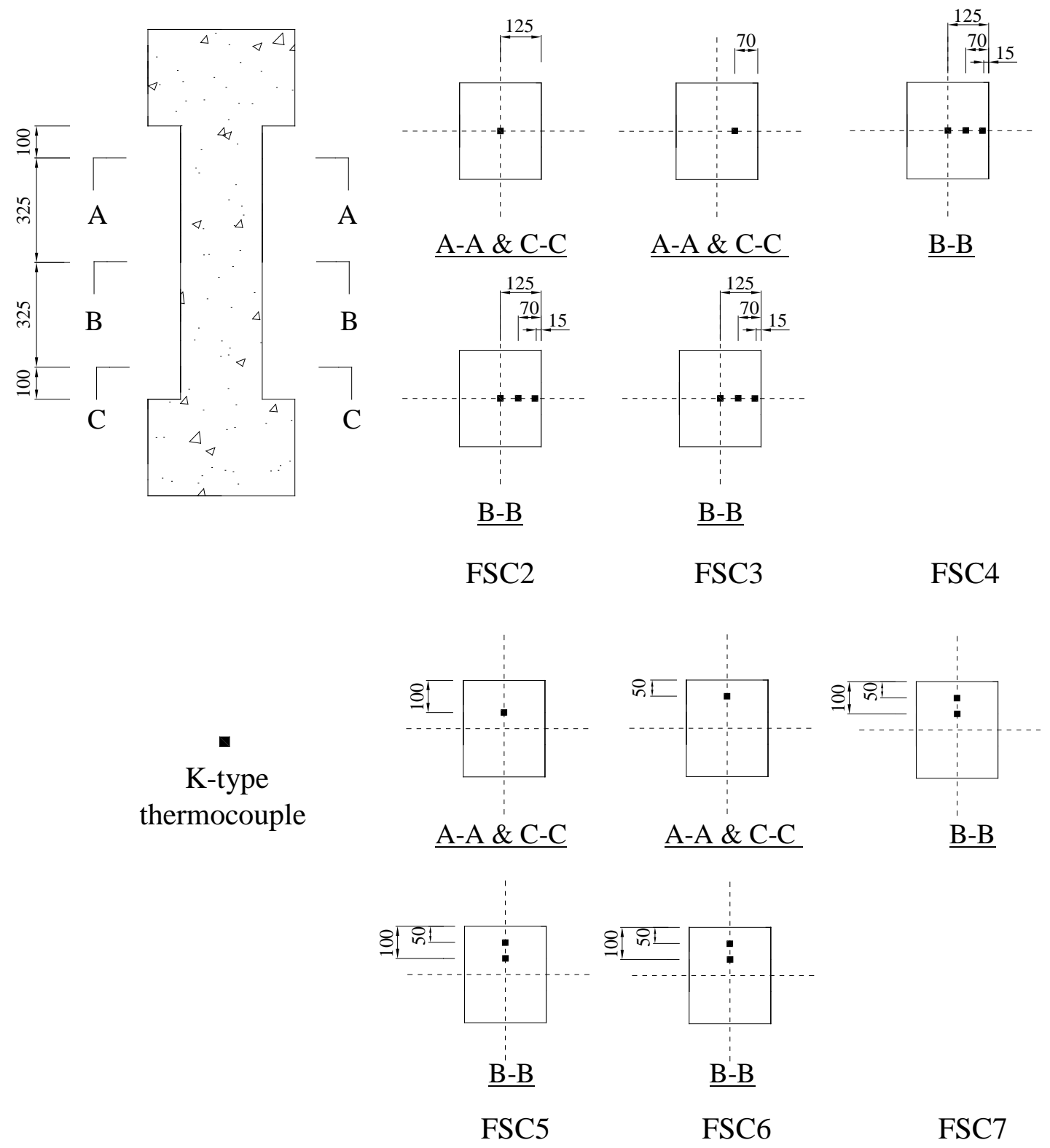

Fig. 3. Positions of the thermocouples in the concrete

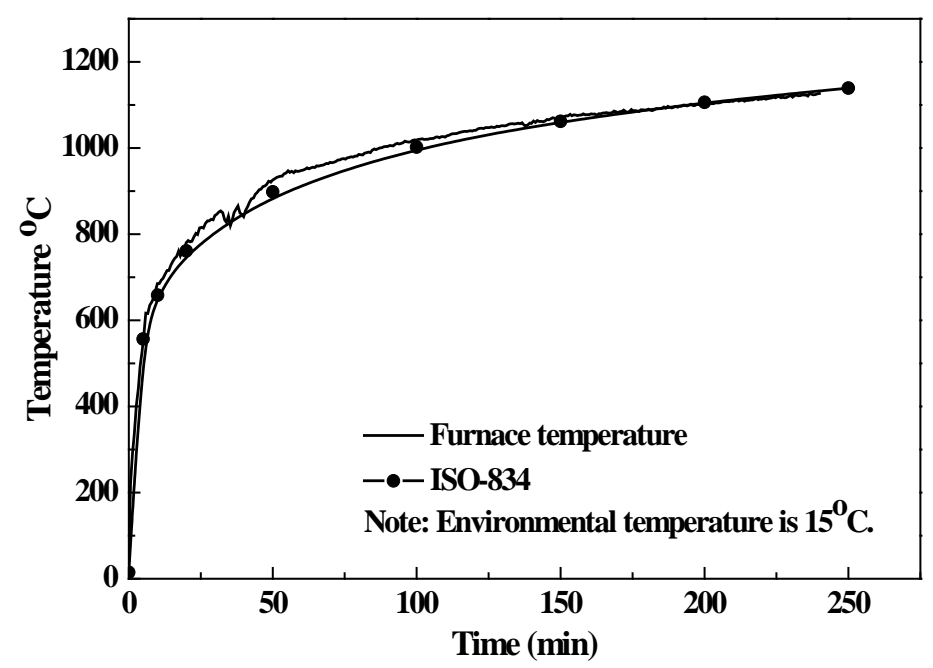

Fig. 4. Measured furnace temperature $(T)$ versus time $(t)$ 

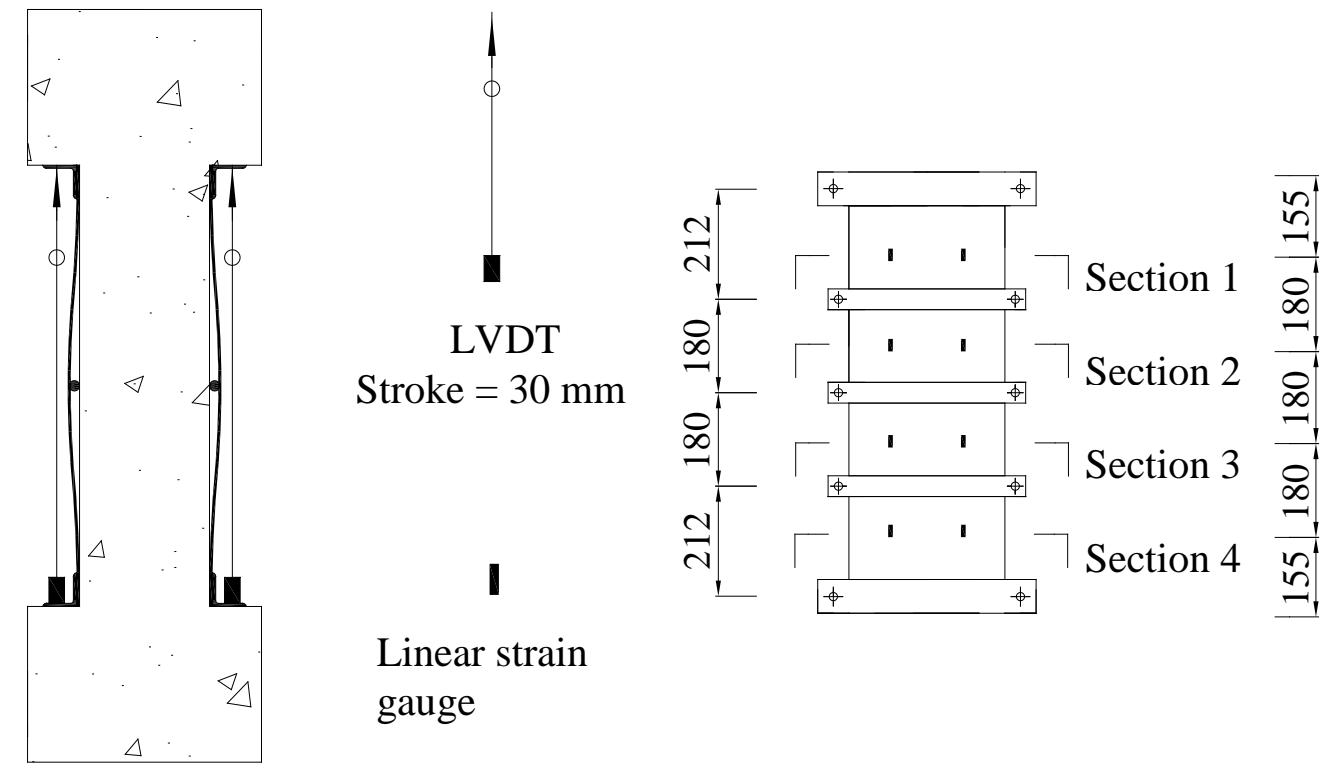

Linear strain

gauge

Fig. 5. Instrumentation of Specimen FSC6

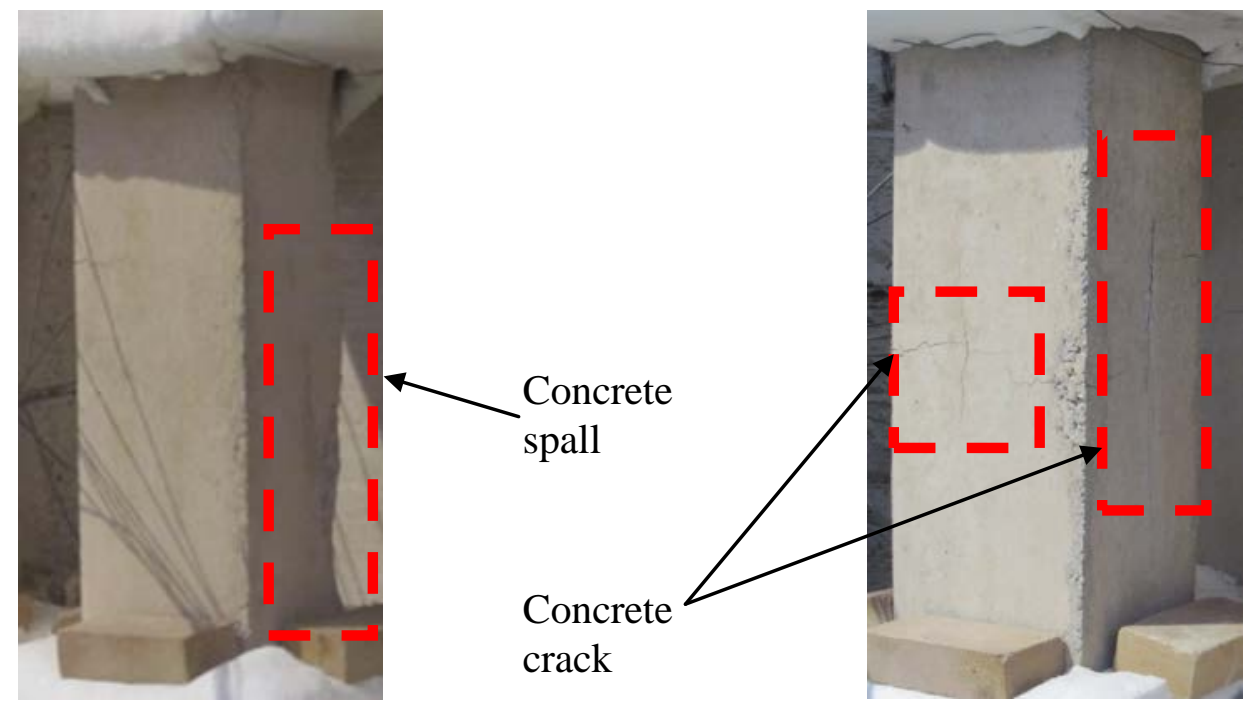

Fig. 6. Crack and spalls of specimens after the fire test 


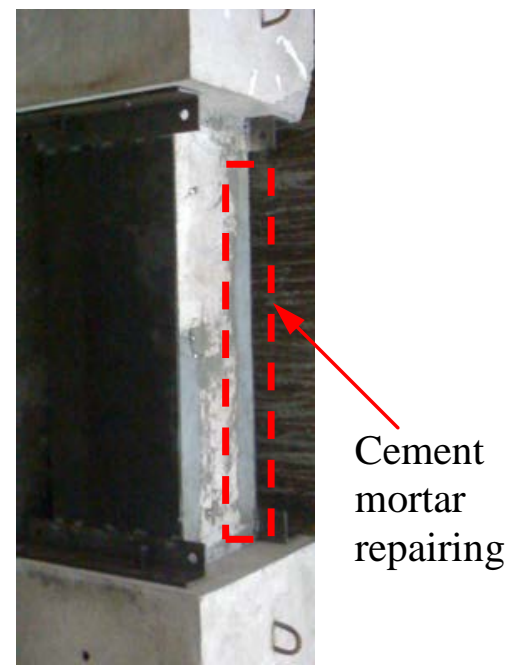

(a)

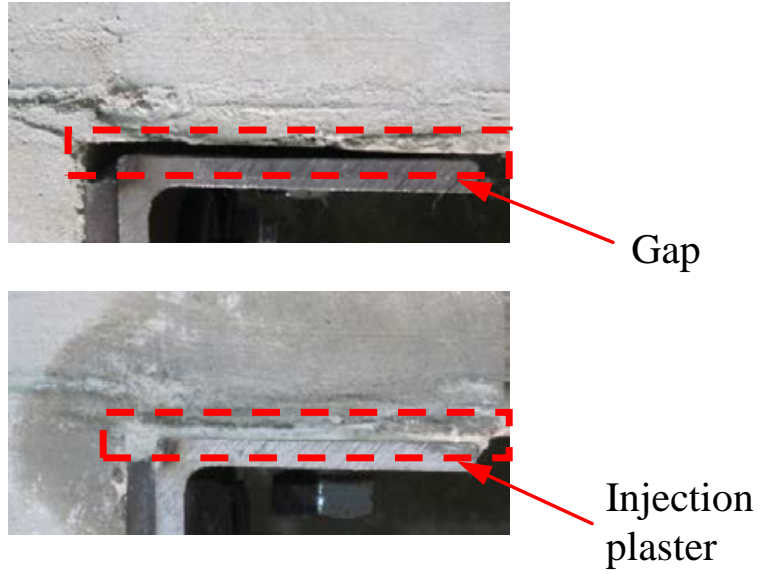

(b)

Fig. 7. Post-stressed procedure (a) Cement mortar repairing of FSC5 and (b) Injection plaster filled in the gaps 


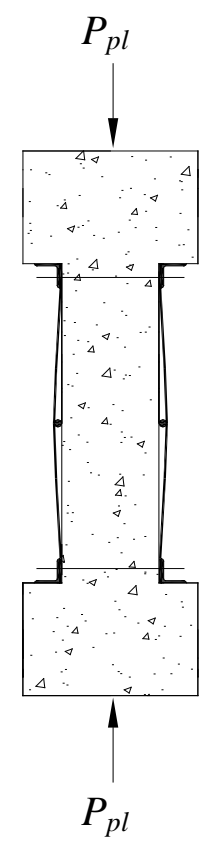

(i) Initial state

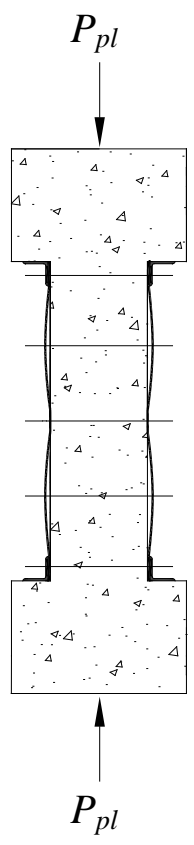

(ii) Tightening the mid-height bolts

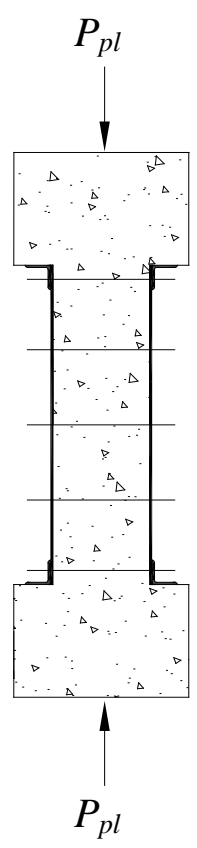

(iii) Flattening the plates

(a)

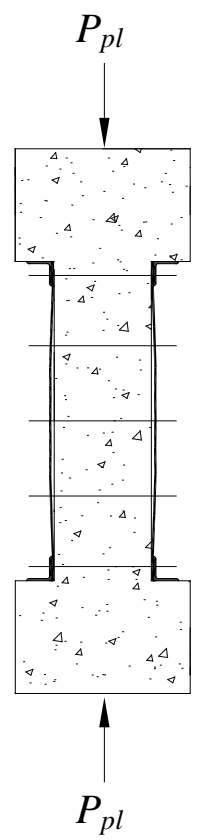

(iv) Loosening the bolts

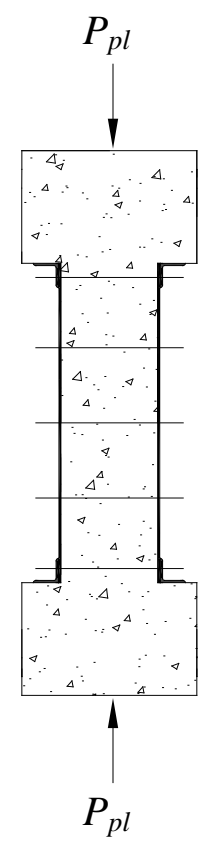

(v) Fastening the bolts again

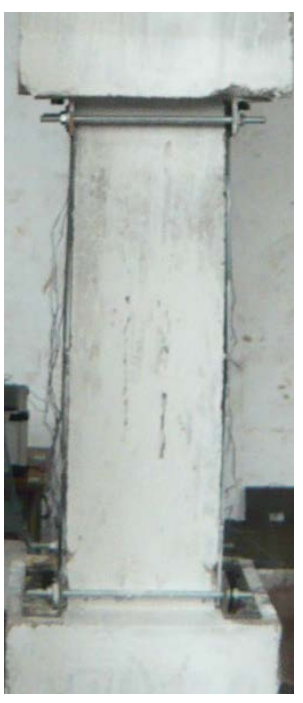

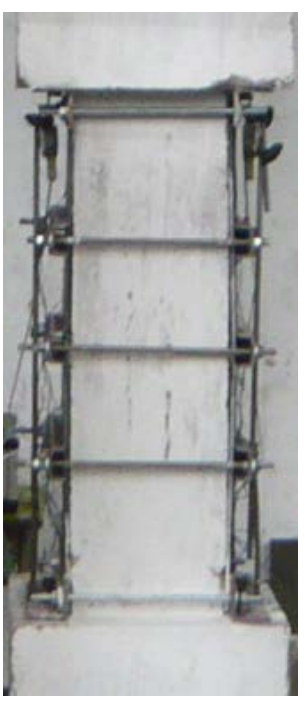

(b)

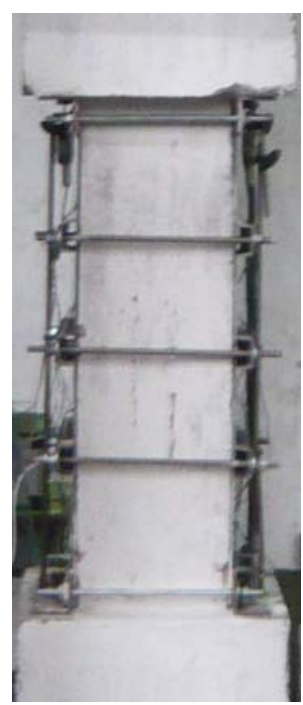

(c)

Fig. 8. Post-stressed procedure (a) Schematic diagram, (b) The Steps (i) to (iii) of FSC6 and (c) Strengthening details of FSC6 


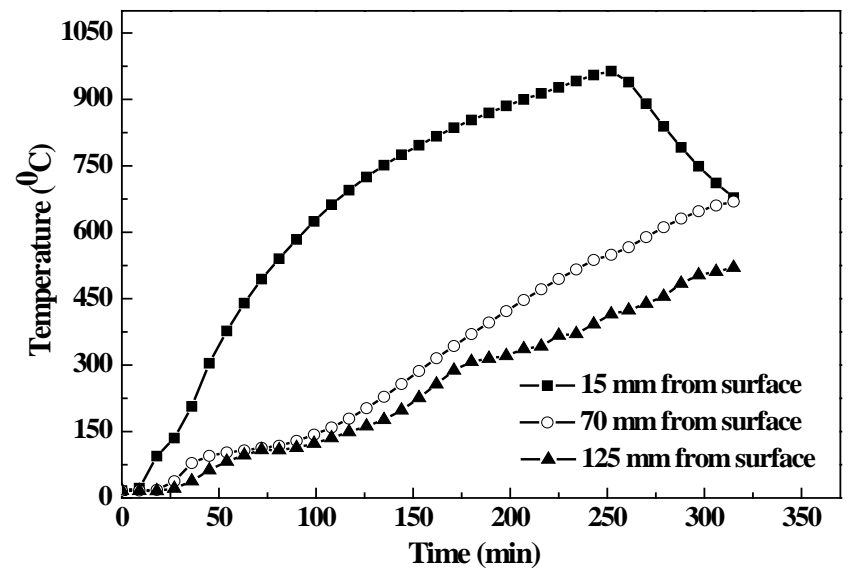

(a)

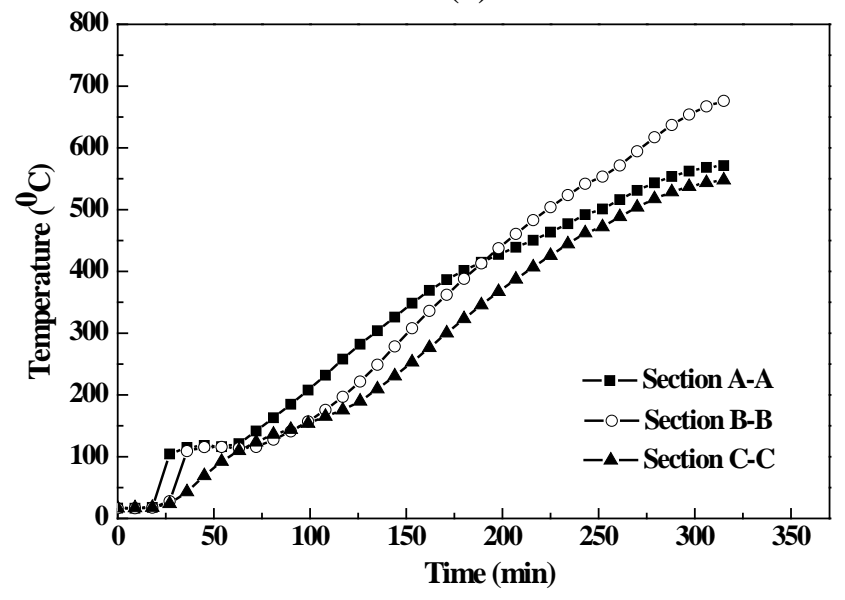

(c)

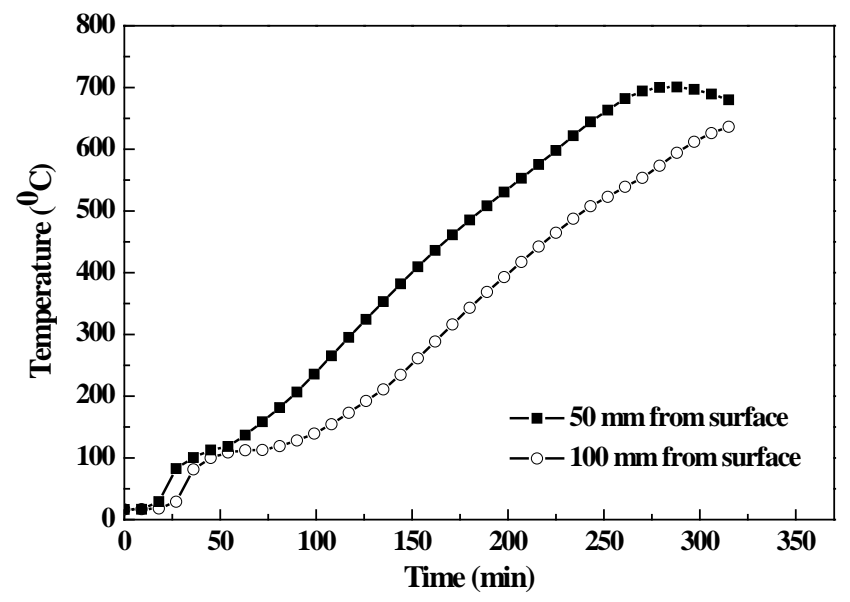

(b)

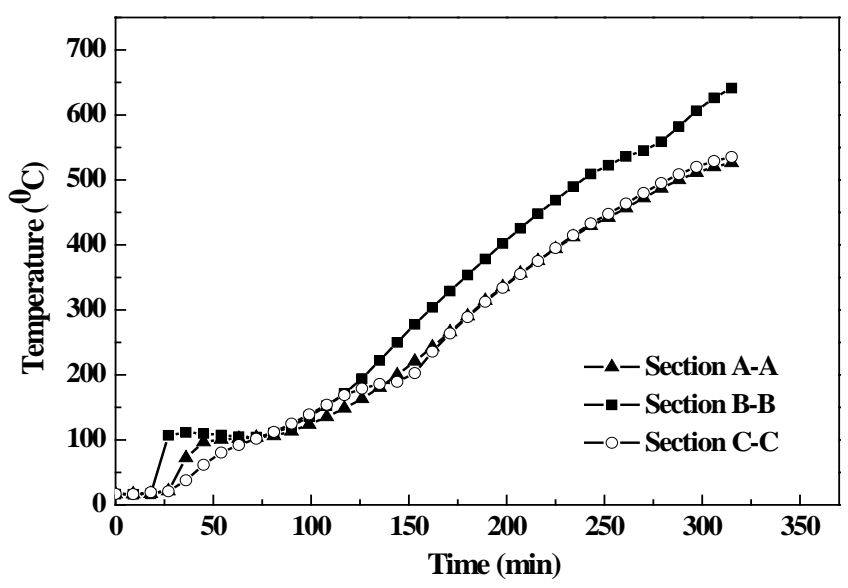

(d)

Fig. 9. Concrete temperature versus time: (a) Section B-B of FSC4; (b) Section B-B of FSC7; (c) $70 \mathrm{~mm}$ from the surface of FSC2; (d) $125 \mathrm{~mm}$ from the surface of FSC5 


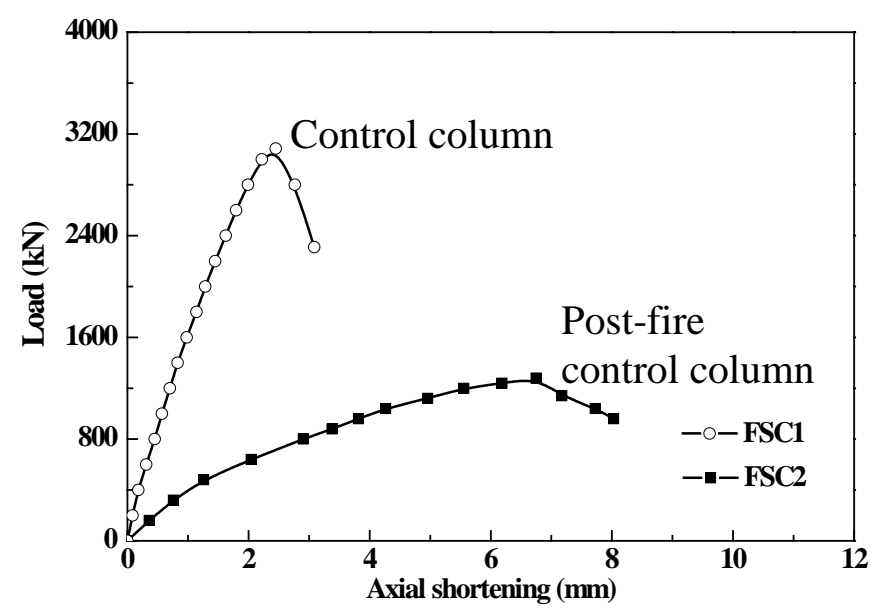

(a)

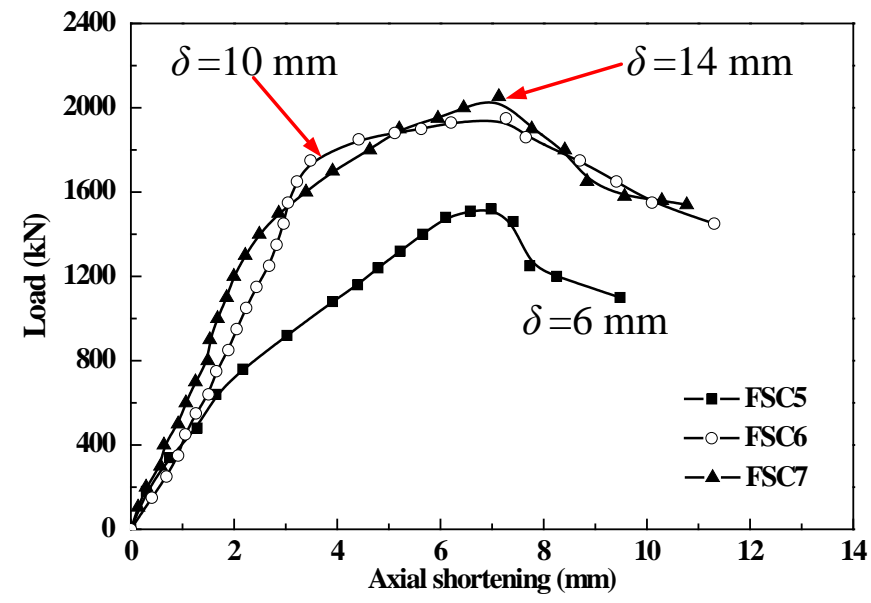

(c)

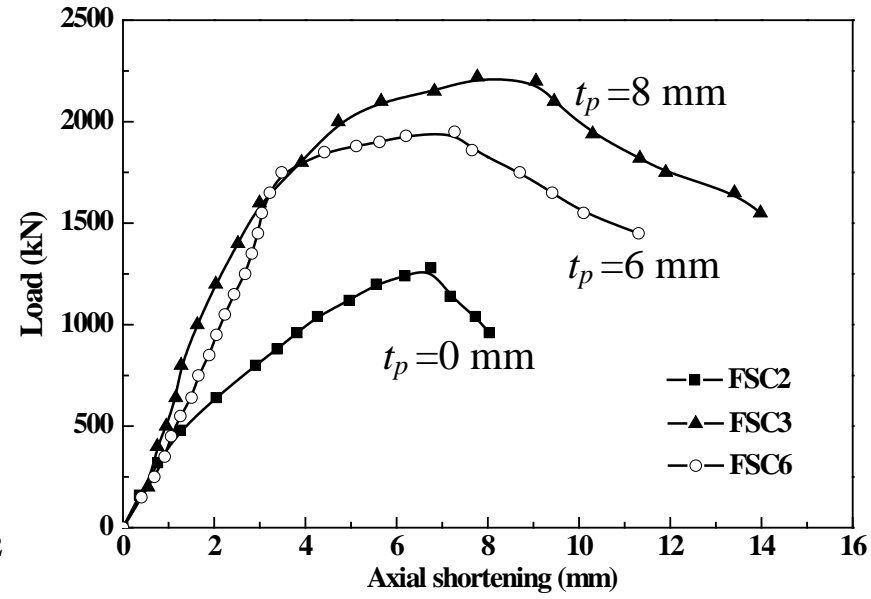

(b)

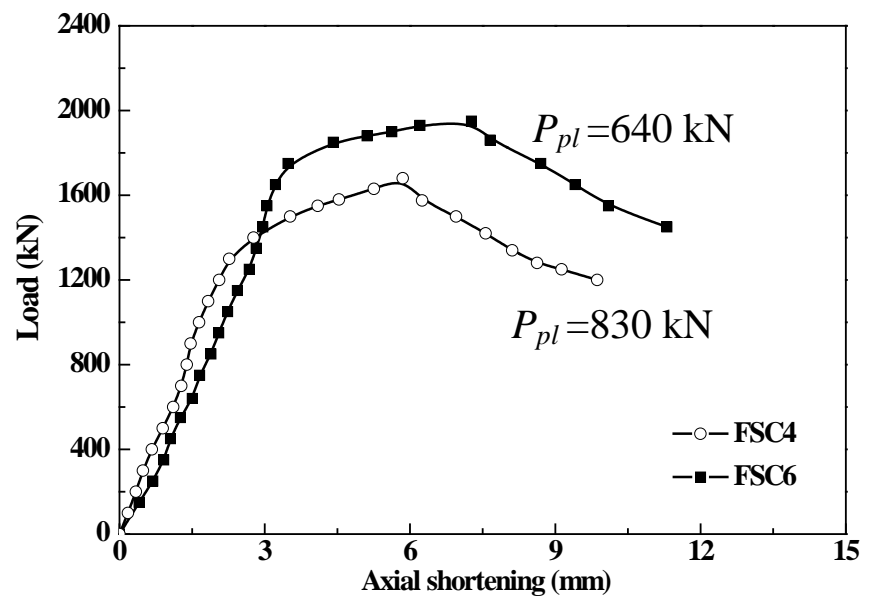

(d)

Fig. 10. Axial compression-shortening curves of specimens: (a) Effects of fire exposure; (b) Effects of plate thickness; (c) Effects of initial precamber; (d) Effects of preloading level

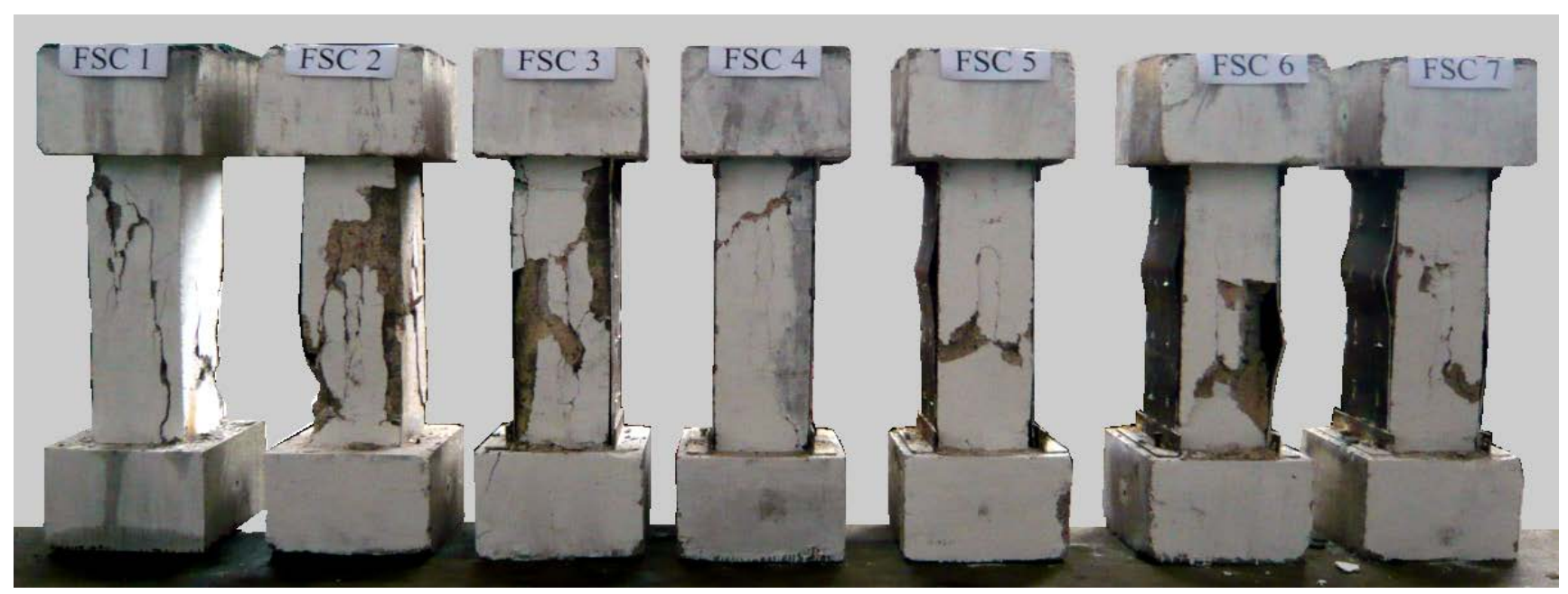

Fig. 11. Crack patterns and failure mode 


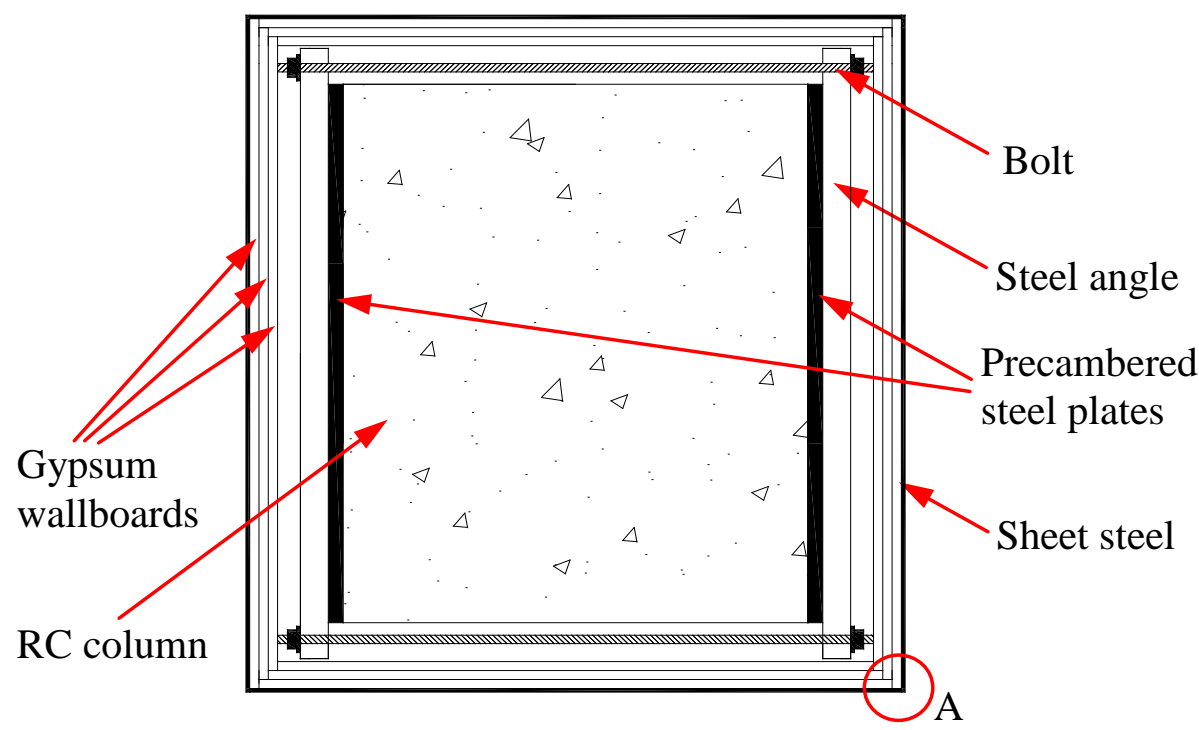

Note: The corner joint details (A) are shown in ASCE/SEI/SFPE 2007.

Fig. 12. Repaired columns fire protected by gypsum wallboard 